\title{
Comparison between the pollution of Mariute lagoon bottom sediments by heavy metals before and after 2015, north Nile Delta, Egypt
}

\begin{abstract}
M.S.M. EL-Bady
Department of Geological Sciences, National Research Centre, El-Buhouth St., Dokki, Cairo, Egypt Received: 10 April 2020 / Accepted 20 July 2020 / Publication date: 30 July 2020

ABSTRACT

This manuscript study the comparison between the pollution of Mariout bottom sediment by heavy metals in 2014 and 2017. All means of heavy metals of bottom sediments collected in 2017 more than that collected in 2014 except Ni. The mean concentrations of heavy metals in Mariute bottom sediments of 2014 and 2017 were arranged in descending order as follows: $\mathrm{Fe}>\mathrm{Mn}>\mathrm{Zn}>\mathrm{Cu}$ $>\mathrm{Pb}>\mathrm{Ni}>\mathrm{Cr}>\mathrm{Cd}$. Degree of contamination (Dc) of the bottom sediments of 2014 and 2017 are ranged from low to moderate degree of contamination (the same except in sample 1). The potential ecological risk index (RI) was low ecological risk in sediments of 2014 and 2017.
\end{abstract}

Keywords: Mariute, bottom sediments, pollution, heavy metals, comparison

\section{Introduction}

The Nile Delta have an arc-shape, where it is arcuated delta, as well as it resembles a triangle. The Nile Delta formed by the sediments comes from the Blue and While Niles. It formed in the north of Egypt from Cairo to the Mediterranean Sea for about $160 \mathrm{~km}$. In general the lagoons classified according to their location, the coastal lagoons such as Mariute, Edku, Burullus, Manzala and Bardaweel, and interior lagoon or lakes such as Qaruon, Rayan and Nasser.

Five lagoons are located on the Mediterranean coast of Egypt, four of them (Mariout, Edku, Burullus and Manzala) are located on the Nile Delta and one lagoon (Bardaweel) located on the east of Suez Canal. Two lagoon are located in Suez canal as a navigation canal (El-Temsah and El-Morra lagoons).

Lagoon Mariut (Mariout, Maryut, Mareotis) (Fig.1) is one of the smallest lagoon in North Delta. It is a small shallow basin located south of Alexandria city and is not linked with the Mediterranean Sea directly. It is a $90-150 \mathrm{~cm}$ deep brackish water lagoon located in the north of Egypt southeast to the Alexandria city, belonging to the Nile River Delta system, and one of the most heavily populated urban areas in Egypt and in the world. It is located at $31^{\circ} 07^{\prime}$ north latitude and $29^{\circ}$ along the 52' East coast of Egypt. Extreme northern point of $31^{\circ} 10^{\prime}$ in the east $-29^{\circ} 56^{\prime}$, in the south $31^{\circ} 04^{\prime}$ to the west $29^{\circ} 51^{\prime}$. It forms the border of the Mediterranean in the south, Mariut Lagoon is $63.47 \mathrm{~km} 2$ (Mateo, 2013). It lost about 25\% from its original size for creation of agriculture lands. Artificially, it is divided into four basins, the lagoon proper, the fish farm, the southeast and the southwest basins, the area of the lagoon proper reaches $27.3 \mathrm{~km} 2$ and its depth ranges from $90-150$ $\mathrm{cm}$. Also Lagoon Mariout is highly polluted with different heavy metals such as iron, copper and zinc (Saad, et al., 1981 and El-Bestawy, 2000). Mariout lagoon receives huge amounts of agricultural discharges loaded with sewage and industrial waste water comes from several drains which considered as the main sources of water reaching the lake (El-kalaa, El-Omoum and Nubaria drains). Saad and Safty, (2004) stated that in the last three decades, Lagoon Mariut become more polluted. This pollution increases with time; due to the successive increase in population and industry around the lagoon different types of untreated pollutants (sewage and industrial wastes and agricultural runoff) entering into the lagoon changed it into a highly eutrophic state. This beside reclamation of great areas from the lagoon has affected dramatically its fish production. In the past, it received unmodified Nile water. All possible environmental problems occurred in Mariut lagoon. Land filling for building houses, infrastructures, and for agriculture has been reducing the area of the Lagoon from $700 \mathrm{~km}^{2}$ to the present $250 \mathrm{~km}^{2}$. All these human activities have critical impacts on the remaining area of the Lagoon (Khalifa and Kondrashin, 2013). Wahaab, and Badawy, (2004) said that the industry uses

Corresponding Author: M.S.M. EL-Bady, Department of Geological Sciences, National Research Centre, Dokki, Cairo, Egypt. E-mail: elbady_nrc@yahoo.com 


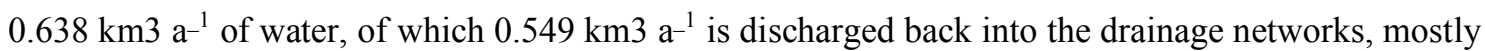
connected to the delta. Hamza, (2006) suggested that the lagoons are supplying to $50 \%$ of the annual Egyptian fish yield. The northern lagoons serve as collection basins for agricultural drainage, municipal sewage, and industrial wastewater. Consequently, Egyptian lagoons are suffering severe ecological risks.

Many authors such as Fu, and Wang, (2011) and El-Halag et al. (2013) stated that the heavy metals can be occurred in the coastal and marine environments due to industries, wastewaters and domestic effluents. In addition, wind and wave action cause the agitation and re- suspension of fine particulate matters, either organic or inorganic, in the surface layer of bottom sediments. Heavy metals are considered a major anthropogenic contaminant in coastal and marine environments worldwide (Ruilian et al., 2008). They pose a serious threat to human health, living organisms and natural ecosystems because of their toxicity, persistence and bioaccumulation characteristics (Deforest et al., 2007). The analysis of heavy metals in sediments permit us to detect pollution that could liberated to water. Also, provides information about the critical sites of the water system under consideration (Fabbri, et al., 2001 and Bordes, and Bourg, 2001).

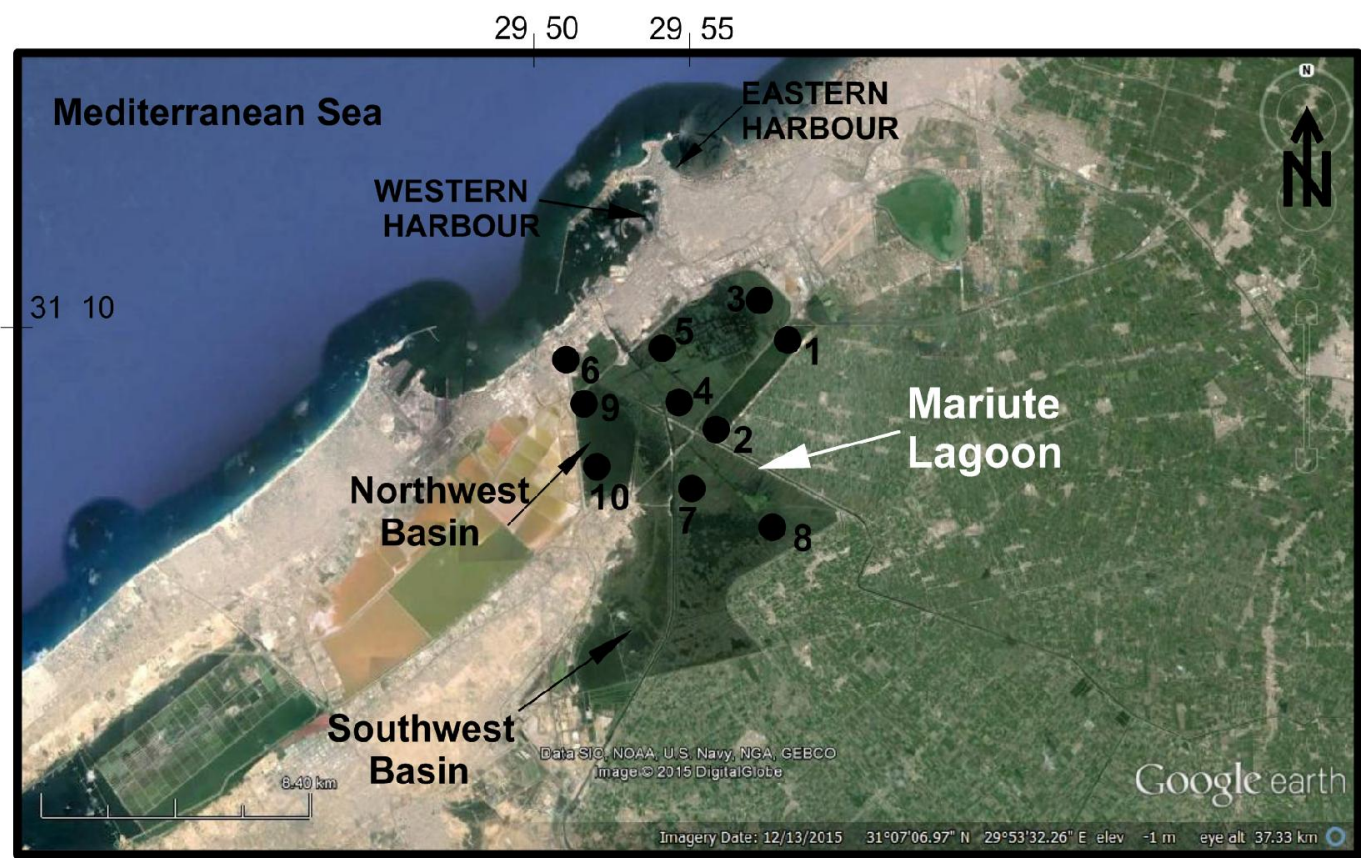

Fig. 1: Location Map of Mariout lagoon (modified after EL-Bady, 2016)

\section{Materials and Methods}

\section{Study area and sampling}

The study area is Mariout lagoon in the north of Egypt to the west of Nile Delta (Fig. 1). 20 surface bottom sediment samples were collected from Mariout lagoon before and after 2015 (10 samples taken from EL-Bady, 2016, samples collected in 2014 and 10 samples collected from the study area by helping Egyptian Environmental Affairs Agency (EEAA, 2017)) (Table. 1).

The use of flame atomic absorption spectrometer is still regarded as the most convenient and appropriate technique for the purpose of heavy metal analysis in most cases. Bottom sediment samples of lagoons were air dried, and then, the $<63 \mu \mathrm{m}$ size fraction was recovered by sieving. This size fraction is widely used to eliminate the effect of particle size and to obtain a more homogeneous grain distribution (Duquesne, et al., 2006). 
Table 1: Locations of collected bottom sediment samples from Mariout lagoon

\begin{tabular}{|c|c|c|c|c|c|}
\hline \multicolumn{6}{|c|}{ Mariute Lagoon } \\
\hline Samples & Stations & & Samples & Stations & \\
\hline 1 & First fish farm (1000 acre) & Fish & 7 & First fish pond 5000 acre & \\
\hline 2 & Last fish farm (1000 acre) & basins & 8 & Last fish nond 5000 acre & $\begin{array}{l}\text { Northwest } \\
\text { basin }\end{array}$ \\
\hline 3 & Front of ElKala drain & & 8 & & \\
\hline 4 & $\begin{array}{l}\text { North east abu Elkher } \\
\text { bridge }\end{array}$ & Main & 9 & $\begin{array}{c}\text { Front of Al Tankea } \\
\text { Algharbia }\end{array}$ & Southwest \\
\hline 5 & Middle of pond 5000 acre & basin & 10 & $\begin{array}{c}\text { Middle of fish pond } 2000 \\
\text { acre }\end{array}$ & hosin \\
\hline 6 & Front of Tolmbat AlMax & & & & \\
\hline
\end{tabular}

\section{Contamination Factor (CF):}

A contamination factor (Tomlinson et al., 1980) is defined as the metal concentration in sediment divided by some background base value for each element. The background value corresponds to the baseline concentrations reported by (Turekian and Wedepohl, 1961) and is based on element abundances in sedimentary rocks (shale). The terminologies used to describe the contamination factor are: $\mathrm{CF}<1$ low contaminated; $1<\mathrm{CF}<3$ moderate contamination; $3<\mathrm{CF}<6$ considerable contamination and $\mathrm{CF}>6$ high contamination.

\section{Degree of contamination (Dc)}

Another index that can be derived from the CF values is the Degree of contamination (Dc) defined as the sum of all contamination factors for a given site (Håkanson,, 1980).

\section{$\mathrm{Dc}=\sum_{1}^{n} \boldsymbol{C F}$}

where $\mathrm{CF}$ is the single contamination factor, and $\mathrm{n}$ is the count of the elements present. Dc values less than $n$ would indicate low degree of contamination; $n \leq D c<2 n$, moderate degree of contamination; $2 n \leq D c<4 n$, considerable degree of contamination; and Dc $>4 n$, very high degree of contamination (Caeiro et al., 2005 and Pekey et al., 2004).

For the description of the degree of contamination in the study area the following terminologies have been used: Dc $<8$ low degree of contamination; $8<\mathrm{Dc}<16$ moderate degree of contamination; $16 \leq \mathrm{Dc}<32$ considerable degree of contamination; Dc $>32$ very high degree of contamination. Where, $\mathrm{n}=8=$ the count of the studied heavy metals.

\section{Ecological risk factor (Er) and potential ecological risk index (RI)}

An ecological risk factor (Eri) to quantitatively express the potential ecological risk of a given contaminant also suggested by Håkanson, (1980).

$$
\operatorname{Er}=\operatorname{Tr} \times \mathbf{C F}
$$

Where $\mathrm{Tr}$ is the toxic-response factor for a given substance, and $\mathrm{CF}$ is the contamination factor. The Tr values of heavy metals suggested by Håkanson, (1980). The Tr values of $\mathrm{Pb}, \mathrm{Cu}, \mathrm{Co}, \mathrm{Cd}, \mathrm{Cr}$, $\mathrm{Ni}$ and $\mathrm{Zn}$ are 5, 5, 5, 30, 2, 3, and 1, respectively. The following terminologies are used to describe the risk factor: $\mathrm{Er}<40$, low potential ecological risk; $40 \leq \mathrm{Er}<80$, moderate potential ecological risk; $80 \leq \mathrm{Er}<160$, considerable potential ecological risk; $160 \leq \mathrm{Er}<320$, high potential ecological risk; and Er $\geq 320$, very high ecological risk.

The potential ecological risk (RI) of the heavy metals is quantitatively evaluated by the potential ecological risk index (Er) (Håkanson, 1980; Zhu et al. 2008), which takes into account both contamination factor $(\mathrm{CF})$, and the "toxic-response" factor.

The potential ecological risk values obtained were compared with categories grade of Er and RI of metal pollution risk on the environment suggested by Håkanson, (1980) and Shi et al. (2010). The potential ecological risk index (RI) was in the same manner as degree of contamination defined as the sum of the risk factors.

$$
\mathbf{R I}=\sum_{1}^{\mathbf{n}} \mathbf{E r}
$$


where Er is the single index of ecological risk factor, and $\mathrm{n}$ is the count of the heavy metal species. The following terminology was used for the potential ecological risk index: $\mathrm{RI}<150$, low ecological risk; $150 \leq \mathrm{RI}<300$, moderate ecological risk; $300 \leq \mathrm{RI}<600$, considerable ecological risk; and $\mathrm{RI}>600$, very high ecological risk (Håkanson, 1980 and Shi et al., 2010). Where, Er and RI denote the potential ecological risk factor of individual and multiple metals, respectively.

\section{Results and Discussion}

\section{Heavy Metals Distribution:}

Distribution of heavy metals in Mariute lagoon are given in tables 2 and 3. The means of heavy metal contents of 2014 are 18384.6, 467.2, 95.6, 79.68, 37.2, 26.82, 55.4, 0.58, Fe, Mn, Zn, Cu, Ni, $\mathrm{Cr}, \mathrm{Pb}$ and $\mathrm{Cd}$ respectively (Table. 2). The means of heavy metal contents of 2017 are 19336.1, 584.8, 138.7, 90.99, 35.6, 30.91, 59.3, 0.683, Fe, Mn, Zn, Cu, Ni, Cr, Pb and Cd respectively (Table. 3). All means of heavy metals of bottom sediments collected in 2017 more than that collected in 2014 except Ni. The mean concentrations of heavy metals in Mariute bottom sediments of 2014 and 2017 were arranged in descending order as follows: $\mathrm{Fe}>\mathrm{Mn}>\mathrm{Zn}>\mathrm{Cu}>\mathrm{Pb}>\mathrm{Ni}>\mathrm{Cr}>\mathrm{Cd}$.

Table 2: Concentration of heavy metals in Mariute Lagoon bottom sediments (2014) (from EL-Bady,

\begin{tabular}{ccccccccc} 
2016) & $\mathbf{F e}$ & $\mathbf{M n}$ & $\mathbf{Z n}$ & $\mathbf{C u}$ & $\mathbf{N i}$ & $\mathbf{C r}$ & $\mathbf{P b}$ & $\mathbf{C d}$ \\
Samples & $\mu \mathrm{g} / \mathrm{g}$ & $\mu \mathrm{g} / \mathrm{g}$ & $\mu \mathrm{g} / \mathrm{g}$ & $\mu \mathrm{g} / \mathrm{g}$ & $\mu \mathrm{g} / \mathrm{g}$ & $\mu \mathrm{g} / \mathrm{g}$ & $\mu \mathrm{g} / \mathrm{g}$ & $\mu \mathrm{g} / \mathrm{g}$ \\
\hline $\mathbf{1}$ & 2541 & 250 & 36 & 2.45 & 7 & 3.2 & 66 & 1.02 \\
$\mathbf{2}$ & 6591 & 290 & 42 & 12.5 & 9 & 5.6 & 82 & 0.2 \\
$\mathbf{3}$ & 25235 & 565 & 45 & 22.3 & 55 & 41 & 25 & 0.06 \\
$\mathbf{4}$ & 25365 & 541 & 125 & 121 & 54 & 35 & 29 & 0.3 \\
$\mathbf{5}$ & 24123 & 457 & 142 & 141 & 41 & 33 & 34 & 0.5 \\
$\mathbf{6}$ & 15324 & 542 & 155 & 99 & 39 & 16 & 55 & 1.11 \\
$\mathbf{7}$ & 27326 & 621 & 162 & 162 & 75 & 56 & 28 & 1.01 \\
$\mathbf{8}$ & 27892 & 639 & 170 & 178 & 71 & 62 & 35 & 0.6 \\
$\mathbf{9}$ & 15214 & 356 & 39 & 55 & 9 & 6.6 & 101 & 0.6 \\
$\mathbf{1 0}$ & 14235 & 411 & 40 & 3.61 & 12 & 9.8 & 99 & 0.4 \\
Means & 18384.6 & 467.2 & 95.6 & 79.68 & 37.2 & 26.82 & 55.4 & 0.58 \\
Average shale & 47200 & 850 & 95 & 45 & 68 & 90 & 20 & 0.3 \\
Tr & & & 1 & 5 & 3 & 2 & 5 & 30 \\
\hline
\end{tabular}

Average shale, after (Turekian and Wedepohl, 1961), Tr, Tr: toxic-response factor of (Håkanson, 1980),1 mg/kg $=1 \mathrm{ug} / \mathrm{g}$

Table 3: concentration of heavy metals in Mariute Lagoon bottom sediments (2018)

\begin{tabular}{ccccccccc}
\hline Samples & $\begin{array}{c}\mathbf{F e} \\
\boldsymbol{\mu g} / \mathbf{g}\end{array}$ & $\begin{array}{c}\mathbf{M n} \\
\mathbf{\mu g} / \mathbf{g}\end{array}$ & $\begin{array}{c}\mathbf{Z n} \\
\mathbf{M g} / \mathbf{g}\end{array}$ & $\begin{array}{c}\mathbf{C u} \\
\mathbf{\mu g} / \mathbf{g}\end{array}$ & $\begin{array}{c}\mathbf{N i} \\
\boldsymbol{\mu g} / \mathbf{g}\end{array}$ & $\begin{array}{c}\mathbf{C r} \\
\boldsymbol{\mu g} / \mathbf{g}\end{array}$ & $\begin{array}{c}\mathbf{P b} \\
\boldsymbol{\mu g} / \mathbf{g}\end{array}$ & $\begin{array}{c}\mathbf{C d} \\
\boldsymbol{\mu g} / \mathbf{g}\end{array}$ \\
\hline $\mathbf{1}$ & 1981 & 290 & 66 & 2.77 & 8 & 4.3 & 68 & 1.07 \\
$\mathbf{2}$ & 7596 & 280 & 72 & 13.7 & 11 & 5.9 & 89 & 0.45 \\
$\mathbf{3}$ & 28239 & 685 & 45 & 32.3 & 58 & 45 & 35 & 0.06 \\
$\mathbf{4}$ & 26366 & 681 & 222 & 161 & 60 & 35 & 29 & 0.5 \\
$\mathbf{5}$ & 27163 & 697 & 242 & 131 & 33 & 44 & 37 & 0.55 \\
$\mathbf{6}$ & 13324 & 588 & 199 & 100 & 33 & 16 & 59 & 1.2 \\
$\mathbf{7}$ & 26321 & 666 & 192 & 192 & 65 & 66 & 38 & 1.1 \\
$\mathbf{8}$ & 28894 & 921 & 270 & 198 & 65 & 77 & 38 & 0.8 \\
$\mathbf{9}$ & 16212 & 552 & 49 & 75 & 11 & 6.8 & 100 & 0.9 \\
$\mathbf{1 0}$ & 17265 & 488 & 30 & 4.2 & 12 & 9.1 & 100 & 0.2 \\
Means & 19336.1 & 584.8 & 138.7 & 90.99 & 35.6 & 30.91 & 59.3 & 0.683 \\
Average shale & 47200 & 850 & 95 & 45 & 68 & 90 & 20 & 0.3 \\
$\mathbf{T r}$ & & & 1 & 5 & 3 & 2 & 5 & 30 \\
\hline
\end{tabular}

Average shale, after [Turekian and Wedepohl, 1961], Tr, Tr: toxic-response factor of [Håkanson,,1980],1 mg/kg $=1 \mathrm{ug} / \mathrm{g}$ 
Heavy metal pollution indices:

The pollution in bottom sediments of Mariout lagoon 2017 can be assessed by determining some of indices such as the contamination factors (CF), degree of contaminations (Dc), and ecological risk index (RI) (Table 4 and 5). Potential ecological risk index (RI) depends on the potential ecological risk factor (Er), the toxic-response factor ( Tr) and the contamination factors (CF).The calculated indices of bottom sediment of 2014 are taken from EL-Bady 2016.

Degree of contamination (Dc) of the bottom sediments of 2014 and 2017 (Table 6 and Fig. 2) are ranged from low to moderate degree of contamination (the same except in sample 1). The potential ecological risk index (RI) was low ecological risk in sediments of 2014 and 2017 (Table. 6 and Fig. 3).

Table 4: Contamination Factors (CF) and degree of contamination (Dc) of the bottom sediments of Mariute Lagoon (2017)

\begin{tabular}{|c|c|c|c|c|c|c|c|c|c|}
\hline Samples & $\begin{array}{c}\mathrm{Fe} \\
\mu \mathrm{g} / \mathrm{g}\end{array}$ & $\begin{array}{c}\text { Mn } \\
\mu \mathrm{g} / \mathrm{g}\end{array}$ & $\begin{array}{c}\mathrm{Zn} \\
\mu \mathrm{g} / \mathrm{g}\end{array}$ & $\begin{array}{c}\mathrm{Cu} \\
\mu \mathrm{g} / \mathrm{g}\end{array}$ & $\begin{array}{c}\mathrm{Ni} \\
\mu \mathrm{g} / \mathrm{g}\end{array}$ & $\begin{array}{c}\mathrm{Cr} \\
\mu \mathrm{g} / \mathrm{g}\end{array}$ & $\begin{array}{c}\text { Pb } \\
\mu \mathrm{g} / \mathrm{g}\end{array}$ & $\begin{array}{c}\mathrm{Cd} \\
\mu \mathrm{g} / \mathrm{g}\end{array}$ & Dc \\
\hline 1 & 0.041 & 0.341 & 0.694 & 0.061 & 0.117 & 0.047 & 3.4 & 3.56 & 8.21 \\
\hline 3 & 0.598 & 0.805 & 0.473 & 0.718 & 0.852 & 0.5 & 1.75 & 0.2 & 5.89 \\
\hline 4 & 0.558 & 0.801 & 2.33 & 3.57 & 0.882 & 0.388 & 1.45 & 1.66 & 11.61 \\
\hline 5 & 0.575 & 0.82 & 2.54 & 2.91 & 0.485 & 0.488 & 1.85 & 1.83 & 11.58 \\
\hline 7 & 0.557 & 0.783 & 2.02 & 4.27 & 0.955 & 0.733 & 1.9 & 3.67 & 14.88 \\
\hline 8 & 0.612 & 1.08 & 2.84 & 4.4 & 0.955 & 0.855 & 1.9 & 2.66 & 15.39 \\
\hline 9 & 0.343 & 0.649 & 0.515 & 1.66 & 0.161 & 0.075 & 5 & 3 & 11.46 \\
\hline 10 & 0.365 & 0.574 & 0.315 & 0.093 & 0.176 & 0.101 & 5 & 0.67 & 7.73 \\
\hline $\mathbf{T r}$ & & & 1 & 5 & 3 & 2 & 5 & 30 & \\
\hline
\end{tabular}

Table 5: Ecological risk factor (Er) and potential ecological risk index (RI) of the bottom sediments of Mariute Lagoon (2017)

\begin{tabular}{|c|c|c|c|c|c|c|c|c|c|}
\hline Samples & $\begin{array}{c}\mathrm{Fe} \\
\mu \mathrm{g} / \mathrm{g}\end{array}$ & $\begin{array}{c}\text { Mn } \\
\mu \mathrm{g} / \mathrm{g}\end{array}$ & $\begin{array}{c}\mathrm{Zn} \\
\mu \mathrm{g} / \mathrm{g}\end{array}$ & $\begin{array}{c}\mathrm{Cu} \\
\mu \mathrm{g} / \mathrm{g}\end{array}$ & $\begin{array}{c}\mathrm{Ni} \\
\mu \mathrm{g} / \mathrm{g}\end{array}$ & $\begin{array}{c}\mathrm{Cr} \\
\mu \mathrm{g} / \mathrm{g}\end{array}$ & $\begin{array}{c}P b \\
\mu \mathrm{g} / \mathrm{g}\end{array}$ & $\begin{array}{c}\mathrm{Cd} \\
\mu \mathrm{g} / \mathrm{g}\end{array}$ & RI \\
\hline 1 & & & 0.694 & 0.305 & 0.351 & 0.094 & 17 & 106.8 & 125.244 \\
\hline 2 & & & 0.757 & 1.52 & 0.483 & 0.13 & 22.25 & 45 & 70.14 \\
\hline 3 & & & 0.473 & 3.59 & 2.556 & 1 & 8.75 & 6 & 22.369 \\
\hline 4 & & & 2.33 & 17.85 & 2.646 & 0.776 & 7.25 & 49.8 & 80.652 \\
\hline 5 & & & 2.54 & 14.55 & 1.455 & 0.976 & 9.25 & 54.9 & 83.671 \\
\hline 6 & & & 2.09 & 11.1 & 1.455 & 0.354 & 14.75 & 120 & 149.749 \\
\hline 7 & & & 2.02 & 21.35 & 2.865 & 1.466 & 9.5 & 110.1 & 147.301 \\
\hline 8 & & & 2.84 & 22 & 2.865 & 1.71 & 9.5 & 79.8 & 118.715 \\
\hline 9 & & & 0.515 & 8.3 & 0.483 & 0.15 & 25 & 90 & 124.448 \\
\hline 10 & & & 0.315 & 0.465 & 0.528 & 0.202 & 25 & 20.1 & 46.61 \\
\hline
\end{tabular}

Table 6: Comparison of the heavy metal pollution indices for Mariout bottom sediments of 2014 and 2017

\begin{tabular}{|c|c|c|c|c|c|c|c|c|}
\hline \multirow[t]{2}{*}{ Samples } & \multicolumn{4}{|c|}{$\begin{array}{c}\text { Mariute Lagoon } 2014 \\
\text { According to EL-Bady, } 2016\end{array}$} & \multicolumn{4}{|c|}{$\begin{array}{l}\text { Mariute Lagoon } 2017 \\
\text { Present study }\end{array}$} \\
\hline & \multicolumn{2}{|c|}{ Dc } & \multicolumn{2}{|c|}{ RI } & \multicolumn{2}{|c|}{ Dc } & \multicolumn{2}{|c|}{ RI } \\
\hline 1 & 7.61 & LDC & 119.53 & LER & 8.21 & MDC & 125.244 & LER \\
\hline 2 & 6.16 & LDC & 42.85 & LER & 7.73 & LDC & 70.14 & LER \\
\hline 3 & 4.88 & $\mathrm{LDC}$ & 18.53 & LER & 5.89 & LDC & 22.369 & LER \\
\hline 4 & 8.81 & $\mathrm{MDC}$ & 55.17 & LER & 11.61 & $\mathrm{MDC}$ & 80.652 & LER \\
\hline 5 & 10.01 & $\mathrm{MDC}$ & 78.20 & LER & 11.58 & MDC & 83.671 & LER \\
\hline 6 & 11.99 & MDC & 139.45 & LER & 12.90 & MDC & 149.749 & LER \\
\hline 7 & 13.10 & $\mathrm{MDC}$ & 132.25 & LER & 14.88 & $\mathrm{MDC}$ & 147.301 & LER \\
\hline 8 & 12.57 & $\mathrm{MDC}$ & 94.82 & LER & 15.39 & MDC & 118.715 & LER \\
\hline 9 & 9.62 & $\mathrm{MDC}$ & 92.31 & LER & 11.46 & MDC & 124.448 & LER \\
\hline 10 & 7.85 & LDC & 66.31 & LER & 7.73 & LDC & 46.61 & LER \\
\hline
\end{tabular}

Low degree of contamination, LDC. Moderate degree of contamination, MDC. Low ecological risk, LER 


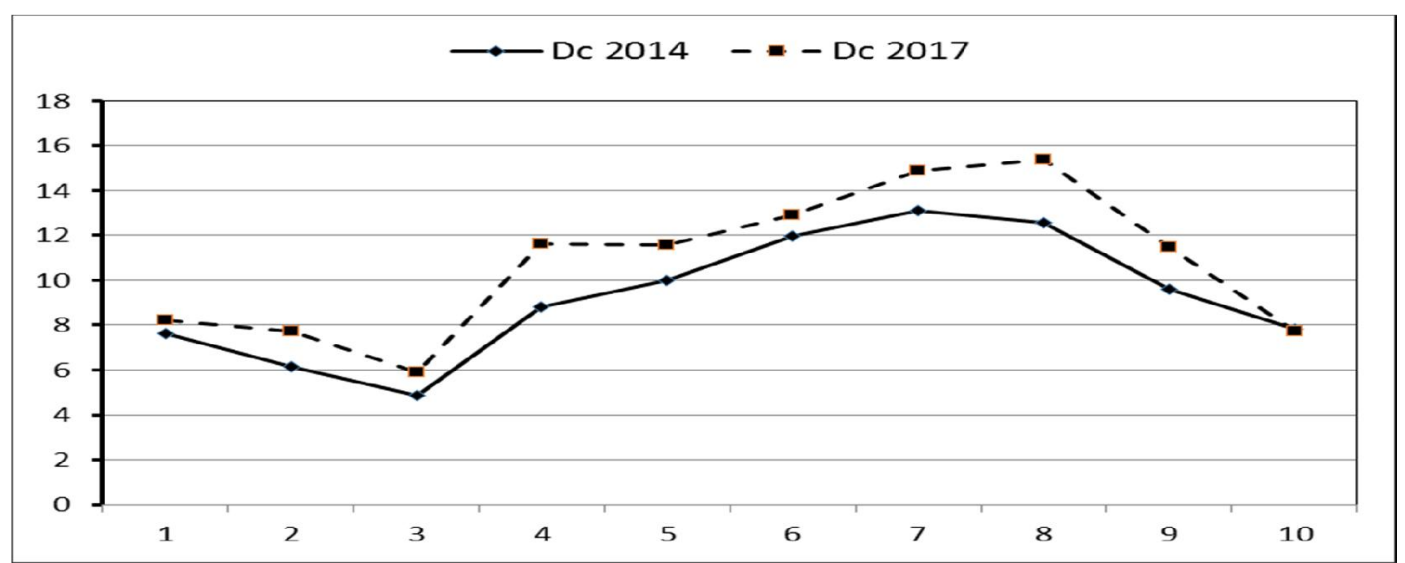

Fig. 2: Degree of contamination of Mariout lagoon bottom sediments of 2014 and 2017

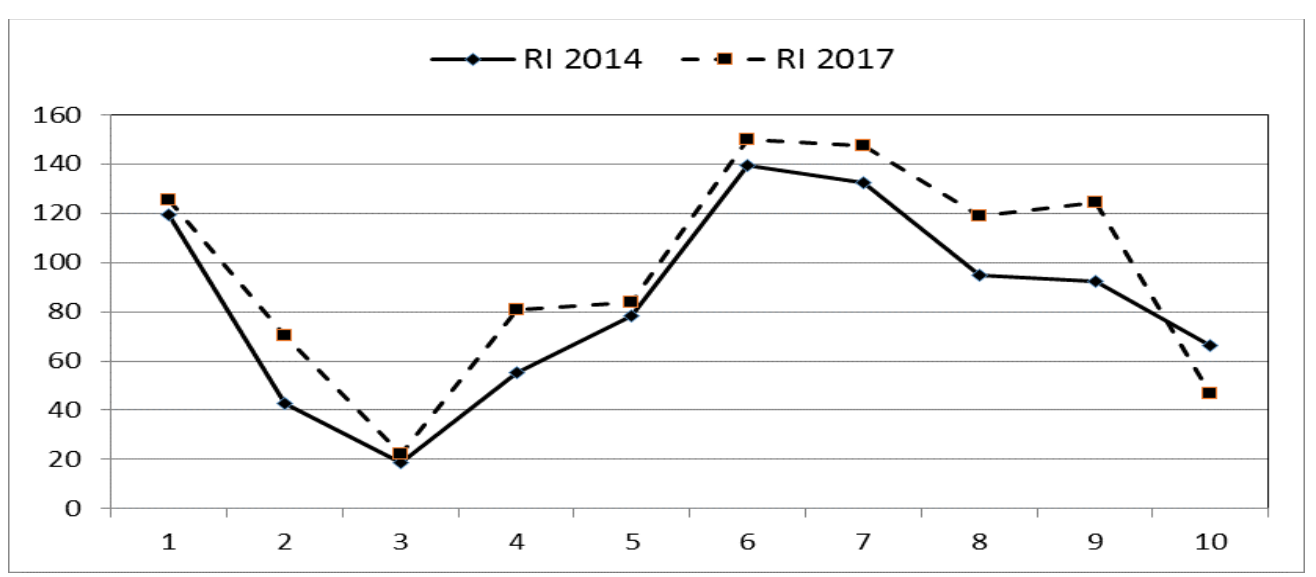

Fig. 3: potential ecological risk index of Mariout lagoon bottom sediments of 2014 and 2017

\section{Conclusion}

The comparison between the pollution of bottom sediments by heavy metals shown that the variation in pollution from 2014 to 2017 is very small. The time period from 2014 to 2017 is very small to change the properties of Mariout lagoon.

\section{References}

Bordes, P. and A. Bourg, 2001. Effect of solid/liquid ratio on the remobilization of $\mathrm{Cu}, \mathrm{Pb}$ and $\mathrm{Zn}$ from polluted river sediment. Water, Air and Soil Pollution 128 (3/4): 391-400.

Caeiro, S., M. H. Costa, and T. B. Ramos, 2005. Assessing Heavy Metal Contamination in Sado Estuary Sediment: An Index Analysis Approach. Ecological Indicators, 5: 151-169.

Deforest, D., K. Brix and W. Adams, 2007. Assessing metal bioaccumulation in aquatic environments: The inverse relationship between bioaccumulation factors, trophic transfer factors and exposure concentration. Aquat. Toxicol., 84: 236-246.

Duquesne, S., L. C. Newton, L. Giusti, S. B. Marriott, A. J. Stark, and D. J. Bird, 2006. Evidence for declining levels of heavy metals in the Severn Estuary and Bristol Channel, U.K., and their spatial distribution in sediments. Environ. Pollut, 143, 187-196.

EL-Bady, M.S.M., 2016. Potential Ecological Risk Index of the Northern Egyptian Lagoons, South of Mediterranean Sea, Egypt . International Journal of ChemTech Research. CODEN(USA): IJCRGG ISSN: 0974-4290 Vol.9,No.03pp 172-190,2016

El-Bestawy E., 2000. "X-Ray Microanalytical Study on Cyclotella meneghiniana (Bacillariophyceae) as a Bioindicator for Metal Pollution in Marine and Fresh Water Environments.", Pakistan Journal of Biological Sciences 3 (9): 1500-1505. 
El-Halag, R.S.F., I.M. Shaker, S.F. Mehanna, M.F. Othman and A.E. Farouk, 2013. Impact of Some Environmental Condition on Water Quality and Some Heavy metals in Water from Bardawil Lake. New York Science Journal 2013;6(11), http://www.sciencepub.net/newyork

Fabbri, P., G. Gabbianelli, C. Locatelli, P. Lubrano, C. Tormbini, and I. Vassura, 2001. Distribution of mercury and other heavy metals in core sediments of northern Adriatic Sea. Water, Air and Soil Pollution 129 (1/4): 143-153.

$\mathrm{Fu}, \mathrm{F}$. and Q. Wang, 2011. Removal of heavy metal ions from wastewaters: a review. J. Environ. Manage., 92: 407-418.

Håkanson, L., 1980. An ecological risk index for aquatic pollution control: A sedimentological approach. Water Res., 14: 975-1001. doi:10.1016/0043-1354(80) 90143-8.

Hamza, W., 2006. The Nile estuary. Handbook of Environmental Chemistry 5,149-173.

Khalifa M. M. and R. V. Kondrashin, 2013. Detect Risk Zone of Heavy Metals Contamination in Water of The Lake Mariut, Alexandria, Egypt. Yestestvennye Nauki (Natural Sciences), 2013, 2 (43).

Mateo M. A., 2013. Lake Mariut: An Ecological Assessment. Blanes, Spain, 2009, 58 p.Availableat:http://www.medcities.org/docs/Lake\%20Maryut\%20Eco\%20Ass.\%20WADI\%20 Project.pdf (Accessed 10 March 2013).

Pekey, H., D. Karakaş, and S. Ayberk, 2004. Ecological Risk Assessment Using Trace Elements from Surface Sediments of İzmit Bay (Northeastern Marmara Sea) Turkey. Marine Pollution Bulletin, 48: 946-953

Ruilian, Y., Y. Xing, Z. Yuanhui, H. Gongren and T. Xianglin, 2008. Heavy metal pollution in intertidal sediments from Quanzhou Bay, China. J. Environ. Sci. 20, 664-669

Saad, M. A. H., A. A. Ezzat, O. A. El-Rayis, and H. Hafez, 1981. "Occurrence and distribution of chemical pollutants in Lake Mariut, Egypt.II. Heavy metals." Water, Air and Soil Pollution, 16 (4): 401-407.

Saad, M.A.H and A.M. Safty, 2004. Environmental Problems in Two Egyptian Shallowlakes Subjected to Different Levels Of Pollution, Eighth International Water Technology Conference, IWTC8 2004, Alexandria, Egypt.

Shi, G., Z. Chen, C. Bi, Y. Li, J. Teng, L. Wang, and S. Xu, 2010. Comprehensive assessment of toxic metals in urban and Suburban Street deposited sediments (SDSs) in the biggest metropolitan area of China. Environ. Pollu., 158: 694-703.

Tomilson, D. C., D. J. Wilson, C. R. Harris, and D. W. Jeffrey, 1980. Problem in assessment of heavy metals in estuaries and the formation of pollution index. Helgol. Wiss. Meeresunlter, 33 (1-4), 566-575 (10 pages).

Turekian, K.K., and K.H. Wedepohl, 1961. Distribution of the elements in some major units of the Earth's crust. Geol. Soc. Am. 72, 175-192.

Wahaab, R.A., and M.I. Badawy, 2004. Water quality assessment of the River Nile system: an overview. Biomedical and Environmental Sciences 17, 87-100

Zhu, W., B. Bian, and L. Li, 2008. Heavy metal contamination of road-deposited sediments in a medium size city of China. Environ. Monit. Assess., 147(1-3): 171-181. doi:10.1007/s10661007-0108-2 